\title{
Protein, calcium and phosphorus requirements in the maintenance of captive-bred capybaras
}

\section{Sérgio Luiz Gama Nogueira-Filho ${ }^{1,2}$, Marco Antônio Galvão de Carvalho ${ }^{1}$, Alcester Mendes ${ }^{1}$, Selene Siqueira da Cunha Nogueira ${ }^{3}$}

\author{
Laboratório de Nutrição de Animais Silvestres, Universidade Estadual de Santa Cruz. \\ ${ }^{2}$ Departamento de Ciências Agrárias e Ambientais, Universidade Estadual de Santa Cruz, Rod. Jorge Amado Km 16, Ilhéus, Bahia, Brazil, $45662-900$. \\ ${ }^{3}$ Laboratório de Etologia Aplicada, Universidade Estadual de Santa Cruz.
}

\begin{abstract}
The objective was to determine the nitrogen-protein, calcium and phosphorus requirements of adult capybaras (Hydrochoerus hydrochaeris) bred in captivity through a nutritional balance study under conditions that favored the occurrence of cecotrophy. In a completely randomized design with four replicates per treatment, 16 adult female capybaras were fed isocaloric diets containing four levels of nitrogen (11.4, 12.3, 15.4 and $18.4 \mathrm{~g} \mathrm{~N} / \mathrm{kg}$ dry matter-DM); calcium (3.0, 3.5, 4.0 and $4.5 \mathrm{~g} \mathrm{Ca} / \mathrm{kg}-\mathrm{DM})$; and phosphorus (2.0, 2.3, 2.7 and $3.0 \mathrm{~g} \mathrm{P} / \mathrm{kg}-\mathrm{DM})$. After 10 days of adaptation, the collection of feces was carried out for five consecutive days. Immediately following fecal collection, the animals were housed in metabolic cages for two days for urine collection. During the fecal collection, capybaras were observed to perform on average $0.32 \pm 0.27$ cecotrophy acts per hour. Regression analyses allowed for estimating daily requirements of $0.25 \mathrm{~g}$ digestible nitrogen $/ \mathrm{kg} \mathrm{LW}{ }^{0.75}$, which equals $1.56 \mathrm{~g}$ of digestible protein $/ \mathrm{kg} \mathrm{LW} \mathrm{LW}^{0.75}$. Likewise, the available calcium and phosphorus requirements in $0.30 \mathrm{~g} \mathrm{Ca} / \mathrm{kg} \mathrm{LW}^{0.75}$ and $0.15 \mathrm{~g} \mathrm{P} / \mathrm{kg} \mathrm{LW}^{0.75}$ were estimated. The requirements of digestible nitrogen, as well as those of available calcium and phosphorus for the maintenance of capybaras are lower than those of domestic and other wild animal species with zootechnical potential.
\end{abstract}

Key Words: capybara nutrition, cecotrophy, digestibility, Hydrochoerus hydrochaeris, nutrient balance, wild animals

\section{Introduction}

Protein requirements of capybaras have been established through nitrogen balance in metabolism trials, without taking into account their cecotrophy behavior (González-Jiménez \& Escobar, 1975). However, successive observations have revealed that these animals have this behavior (Borges et al., 1996). Cecotrophy is part of the feeding strategy of some rodents and lagomorphs, and is characterized by the intake of a different kind of excreta with high microbial protein content (Cheeke, 1987; Gross \& Spillman, 2003). Hence, establishing the nutritional needs of animals from this species requires knowledge of the contributions of nitrogen and other nutrients in the process of cecotrophy.

The determination of protein requirements, either for maintenance or growth and reproduction purposes, is essential for the success of capybara commercial breeders. Besides acting in the building and repair of tissues, proteins are essential to promote proper biological functioning (Pond et al., 2004). The daily requirement for digestible protein (DP) of capybaras is relatively low: $2.5 \mathrm{~g} \mathrm{DP} / \mathrm{kg} \mathrm{LW}^{0.75}$ (González-Jiménez \& Escobar, 1975), whereas Nellore cattle (Bos indicus) require $4.0 \mathrm{~g} \mathrm{DP} / \mathrm{kg} \mathrm{LW}^{0.75}$ (Véras et al., 2007).
Besides proteins, minerals are essential for adequate nutrition. The importance of minerals lies in the fact that they are effective components of metabolism, reflecting higher or lower animal productivity (Maynard et al., 1984). Nonetheless, there is no information on requirements of capybaras for minerals and, for this reason, the ad libitum supply of mineral salt formulated for beef cattle is recommended (Nogueira-Filho \& Nogueira, 2004). Accordingly, there is a need for determining the requirements of adult capybaras for nitrogen-protein, calcium and phosphorus.

\section{Material and Methods}

The experiment was conducted at Laboratório de Nutrição de Animais Silvestres, Universidade Estadual de Santa Cruz-UESC, Ilhéus, Bahia, Brazil. The protocol for this experiment was approved by the Ethics Committee on Animal Use (CEUA) of UESC. Sixteen adult female capybaras weighing on average $38.4 \pm 12.0 \mathrm{~kg}$ were selected according to body mass and ease in forming groups of four specimens of homogeneous weight. With a completely randomized design, the animals were subjected to different experimental treatments. 
After being weighed and dewormed, the animals were housed in individual $11.3 \mathrm{~m}^{2}(7.5 \mathrm{~m} \times 1.5 \mathrm{~m})$ pens. Each pen was partially covered $\left(9.0 \mathrm{~m}^{2}\right)$, with a solarium area of $2.3 \mathrm{~m}^{2}$; both areas had concrete floors. There was a net wire fence partition equipped with a wooden guillotinetype door located between the covered and the solarium areas. Furthermore, all of them had a feeder $(1.10 \times 0.25$ $\times 0.15 \mathrm{~m})$ and a drinking trough $(0.2 \times 0.2 \times 0.2 \mathrm{~m})$. So as to permit physical, visual, auditory and olfactory contact among animals, in an attempt to reduce the stress caused by isolation, since this is a species with highly social behavior, the wall partitions consisted of $1.5 \mathrm{~m}$ high wire fencing. The animals that lived in the same paddock were placed side by side so as to avoid the common conflicts between individuals of different groups (Nogueira et al., 1999). These pens were built in a similar way to those described by Mendes et al. (2000), where capybaras presented cecotrophy behavior. Before the onset of nutritional balance studies, the capybaras underwent a 10-day period of adaptation to the experimental conditions and were fed the same diet they used to receive in their home paddocks.

After the period of adaptation to the experimental conditions, the capybaras were once again weighed. Then, the animals began receiving, in a random manner, one of the four treatments containing four levels of nitrogen (11.4, 12.3, 15.4 and $18.4 \mathrm{~g} \mathrm{~N} / \mathrm{kg}$ dry matter-DM), calcium (3.0, $3.5,4.0$ and $4.5 \mathrm{~g} \mathrm{Ca} / \mathrm{kg}-\mathrm{DM})$ and phosphorus $(2.0,2.3$, 2.7 and $3.0 \mathrm{~g} \mathrm{P} / \mathrm{kg}-\mathrm{DM})$, with the same amount of calories $(3,386.7 \pm 64.1 \mathrm{kcal} / \mathrm{kg}-\mathrm{DM})$ (Table 1$)$.

These treatments consisted of elephant grass $\mathrm{cv}$. Napier (Pennisetum purpureum) and a mixture of ground corn, soybean meal, dicalcium phosphate and limestone. Likewise, fixed values of salt $(3.5 \mathrm{~g} / \mathrm{kg}-\mathrm{DM})$ and mineral premix $(0.1 \mathrm{~g} / \mathrm{kg}$-DM $)$ were added. The same forage: concentrate ratio $(0.7: 0.3)$ and the same previously provided amount $(260 \mathrm{~g} / \mathrm{kg}$ of body weight) were maintained and water was offered ad libitum.

After 10 days of adaptation to the new diets, access to the solarium area was restricted and fecal collection was carried out for five consecutive days. The experimental diets were provided daily at $17 \mathrm{~h} 00$. Before the animals were fed, the diets were duly homogenized for sampling, and the samples were placed in labeled plastic bags. Fecal collection involved three people who worked eight-hour shifts. When there were feces in the pens, the door that provided access to the solarium was opened. Immediately after the animals moved into the solarium area, all feces were directly collected from the floor and packed in previously identified plastic bags. This procedure prevented the trampling of feces and their contamination with urine. After collection, the animals were returned to the covered sections of pens. Feces were then identified, weighed and stored in a freezer at minus $20^{\circ} \mathrm{C}$ for follow-up analysis.

After the end of this period, the capybaras were housed in metabolic cages $(1.2 \times 0.8 \times 0.8 \mathrm{~m})$ located within the pens, where they were maintained for two consecutive days for urine collection. Urine collection was carried out during a different period because under these conditions - kept in metabolic cages that allowed urine collection - capybaras might not present cecotrophy behavior, as observed in the study of González-Jiménez et al. (1976). Equipped with a feeder $(1.10 \times 0.25 \times 0.15 \mathrm{~m})$ and a drinking trough ( $0.2 \mathrm{~m}$ diameter), these cages were placed $1.0 \mathrm{~m}$ above the floor, held up by a wooden structure, and fitted with urine collectors on the base. The cages were also made with wire mesh, thus allowing visual, auditory and olfactory contact with animals in neighboring pens. Upon completion of the test, the capybaras were weighed again and $5.0 \mathrm{~mL}$ blood samples were collected from the cephalic vein using a vacuum collection tube for hematological standard studies. Following these procedures, the animals were transported to their home paddocks.

When the animals were maintained in cages, urine was collected in $1.5 \mathrm{~L}$ glass containers. Each container had $50 \mathrm{~mL}$ of $50 \%$ sulfuric acid for preventing nitrogen loss. The containers were replaced twice daily to avoid contamination and possible nitrogen losses. After the urine volume in the containers had been measured using a beaker, the amount of acid was deducted and an aliquot of $10 \mathrm{~mL}$ of urine was transferred to a previously identified plastic container and weighed for density determination. These aliquots were stored in a refrigerator at $4{ }^{\circ} \mathrm{C}$ for further analysis. During

Table 1 - Composition of experimental diets

\begin{tabular}{lcccc}
\hline & Treatment 1 & Treatment 2 & Treatment 3 & Treatment 4 \\
\hline Nitrogen (g/kg-DM) & 11.4 & 12.3 & 15.4 & 18.4 \\
Calcium (g/kg-DM) & 3.0 & 3.5 & 4.0 & 4.5 \\
Phosphorus (g/kg-DM) & 2.0 & 2.3 & 2.7 & 3.0 \\
Salt (g/kg-DM) & 3.5 & 3.5 & 3.5 & 3.5 \\
Mineral premix ${ }^{1}$ (g/kg-DM) & 0.1 & 0.1 & 0.1 & 0.1 \\
Digestible energy (Kcal/kg) & $1,712.4$ & $1,852.2$ & $1,631.0$ & $1,815.8$ \\
\hline
\end{tabular}

${ }^{1}$ Mineral premix formulated for use in pig feeding with levels of assurance: $\mathrm{Fe}-180 \mathrm{mg} / \mathrm{kg}$; $\mathrm{Cu}-20 \mathrm{mg} / \mathrm{kg} ; \mathrm{Co}-4 \mathrm{mg} / \mathrm{kg} ; \mathrm{Mn}-80 \mathrm{mg} / \mathrm{kg} ; \mathrm{Zn}-140 \mathrm{mg} / \mathrm{kg}$; I - $4 \mathrm{mg} / \mathrm{kg}$. DM - dry matter. 
feces and urine collections, the feed troughs did not have any orts.

Behavioral observations were performed to verify the presence of cecotrophy and evaluate whether the nitrogen and mineral levels in the diets affected its occurrence. During three of the five days assigned for fecal collection, an observer stayed at 1.5 meters from the front of the pens, for two consecutive hours (from $08 \mathrm{~h} 00$ to 10h00), and recorded the occurrence of cecotrophy using the recording methodology described by Altmann (1974). The observed behavior of every animal was totaled over the three days of observation and the final value was divided by the total number of hours of observation, to calculate the hourly frequency.

After collection, feces and feed samples were sent for analysis following the procedures described by Nogueira \& Souza (2005). Chemical analyses were performed at Laboratório de Nutrição Animal of UESC, while calcium and phosphorus analyses were done at Laboratório de Análises de Tecidos Vegetais of Centro de Pesquisa do Cacau of Comissão Executiva do Plano da Lavoura Cacaueira (CEPEC/CEPLAC). Nitrogen levels in feed, feces and urine were determined in nitrogen distillers using the method proposed by Kjeldahl. Gross energy (GE) of feed, feces, and urine samples were determined in a Parr Adiabatic Bomb Calorimeter. Phosphorus content was determined using the method of molybdate reaction, and reading was done in a spectrophotometer. Calcium content was determined by ethylene flame atomic-absorption spectrophotometry.

Blood samples were sent to Hospital Veterinário of UESC and analyzed according to the methodology described in Madella et al. (2006). Hematimetric indices were calculated using the results determined in the red series. The mean corpuscular volume (MCV) was expressed in femtoliters (fL), whereas the mean corpuscular hemoglobin concentration (MCHC) was expressed in $\mathrm{g} / \mathrm{dL}$.

To determine the digestibility coefficients of dry matter, energy and nitrogen, and calcium and phosphorus availability, the equations proposed by Pond et al. (2004) were used:

Equation (1): Coefficient of dry matter digestibility:

$$
(1-\mathrm{f} / \mathrm{a})
$$

Equation (2): Digestibility/availability coefficient of energy and elements:

$$
(1-\mathrm{f} * \mathrm{fn} / \mathrm{a} * \text { an })
$$

Where: $\mathrm{f}=$ dry matter content of feces; $\mathrm{a}=$ dry matter content of feed; $f n=$ element proportion in the dry matter content of feces; an = element proportion in the dry matter content of feed; The daily intakes per kg of metabolic live weight $\left(\mathrm{kg} \mathrm{LW}{ }^{0.75}\right)$ of apparent digestible energy (DE), apparent digestible nitrogen (DN), apparent available calcium (ACa) and apparent available phosphorus (AP) were determined by multiplying the digestibility/availability coefficients of energy, nitrogen, calcium and phosphorus determined by the equations described above by energy concentration and other elements in the feed dry matter and dividing the value obtained by $\mathrm{LW}^{0.75}$. This calculation was based on the body weight of animals corrected for the period of fecal collection.

A linear regression analysis between total nitrogen intake and DN intake was carried out next. The metabolic fecal nitrogen (MFN) value was determined by the equation obtained through linear regression analysis; the result was the amount of nitrogen excreted when under zero nitrogen intake condition. The same procedures were used to estimate amounts of calcium $(\mathrm{Ca})$ and phosphorus $(\mathrm{P})$ present in the feces of metabolic origin (MFCa and MFP, respectively). These values, multiplied by the DMI for each animal, were subtracted from the fecal N, Ca and $\mathrm{P}$ contents in calculating true digestibility/availabilities (Pond et al., 2004).

Urinary excretion of nitrogen $\left(\mathrm{g} / \mathrm{kg} \mathrm{LW}{ }^{0.75}\right)$, calcium $\left(\mathrm{g} / \mathrm{kg} \mathrm{LW}{ }^{0.75}\right)$ and phosphorus $\left(\mathrm{g} / \mathrm{kg} \mathrm{LW}^{0.75}\right)$ was regressed on truly digestible $\mathrm{N}(\mathrm{TDN})$, truly available $\mathrm{Ca}$ (TACa) and truly available $\mathrm{P}$ (TAP) intakes, respectively, to determine endogenous urinary nitrogen (EUN), endogenous urinary calcium (EUCa) and endogenous urinary phosphorus (EUP) under zero intake conditions.

A new linear regression analysis between $\mathrm{DN}$ intake and nitrogen balance $(\mathrm{NB}=\mathrm{N}$ intake - total $\mathrm{N}$ excreted in feces and urine) allowed for estimating the digestible nitrogen demands of capybaras $/ \mathrm{kg} \mathrm{LW}^{0.75}$ when the nitrogen balance was under null conditions ( $\mathrm{NB}=$ zero). The nitrogen value obtained was multiplied by 6.25 to estimate the daily requirement, in digestible protein per $\mathrm{kg} \mathrm{LW}^{0.75}$, for the maintenance of adult capybaras. The same procedures were used to estimate the daily requirements of $\mathrm{Ca}$ and available $\mathrm{P} / \mathrm{kg} \mathrm{LW} \mathrm{W}^{0.75}$ in the maintenance of adult capybaras.

The data for body weight; intakes of DM, GE, N, Ca, and $\mathrm{P} / \mathrm{kg} \mathrm{LW}{ }^{0.75}$; digestibility/availability coefficients of $\mathrm{DM}, \mathrm{GE}, \mathrm{Ca}$, and $\mathrm{P}$; as well as the cecotrophy frequency and results of red series and hematimetric indices of capybaras subjected to different treatments were compared by ANOVA tests followed by Tukey post-hoc test, when appropriate. Prior to such analyses, the Lilliefors test was applied for testing the normal distribution of data.

By employing the Pearson correlation matrix between the intake of $\mathrm{N}, \mathrm{Ca}$ and $\mathrm{P} / \mathrm{kg} \mathrm{LW}^{0.75}$ and cecotrophy frequency, it was found that the $\mathrm{N}, \mathrm{Ca}$ and $\mathrm{P}$ levels in 
the treatments affected the cecotrophy behavior. Also, a linear regression analysis was done to assess the different intake levels of $\mathrm{DE} / \mathrm{kg} \mathrm{LW} \mathrm{LW}^{0.75}$ in comparison with $\mathrm{NB}$, and thus to verify if the amount of consumed DE affected the amount of excreted N. All this was done because when the energy requirements are not met by the diet, the organism is likely to mobilize the muscle protein by establishing a negative energy balance (Kolb, 1984). Finally, a regression analysis comparing the intake values of $\mathrm{N} / \mathrm{kg} \mathrm{LW} \mathrm{LW}^{0.75}$ and MCV indices was carried out. For all statistical analyses, the BioEstat program (version 5.0) was used, applying a significance level of 0.05 .

\section{Results}

For three days, in the period of fecal collection, 32 cecotrophy acts were observed. Capybaras were seen to perform on average $0.32 \pm 0.27$ cecotrophic acts per hour. The occurrence of this behavior did not differ between the experimental diets $(\mathrm{F}=0.20, \mathrm{P}>0.05)$ and was not affected by levels of nitrogen, phosphorus or calcium consumed $(\mathrm{P}>0.05)$. Great individual variability in achieving this act was observed, however, which might have interfered with the analysis (Table 2).

Mean hematocrit values (\%), as well as hemoglobin and mean corpuscular hemoglobin concentration $(\mathrm{CHC})$ values did not vary as a function of the applied treatment (Table 2). Nevertheless, the treatments $(\mathrm{F}=4.95, \mathrm{P}<0.05)$ were observed to affect the mean corpuscular volume, which may indicate anemia (Table 2).

The average daily intakes of DM/kg LW ${ }^{0.75}, \mathrm{GE} / \mathrm{kg} \mathrm{LW}^{0.75}$ and $\mathrm{DE} / \mathrm{kg} \mathrm{LW}{ }^{0.75}$ were similar in all treatments (Table 2). Yet, N, Ca and $\mathrm{P}$ intake patterns were observed to vary according treatments (Table 2). Indeed, because of the different amounts of these elements in the experimental diets, this was already expected. The different intake levels of these elements, however, did not affect the digestibility of: DM (0.53 $\pm 0.05, F=2.69, \mathrm{P}>0.05), \mathrm{GE}(0.52 \pm 0.06$, $\mathrm{F}=1.82, \mathrm{P}>0.05)$ and $\mathrm{N}(0.63 \pm 0.10, \mathrm{~F}=1.42, \mathrm{P}>0.05)$. Furthermore, there were treatment effects on the $\mathrm{N}$ levels of feces $(\mathrm{F}=3.85, \mathrm{P}<0.05)$, urine $(\mathrm{F}=19.80, \mathrm{P}<0.05)$ and nitrogen balance $(\mathrm{NB})(\mathrm{F}=5.60, \mathrm{P}<0.05$, Table 2$)$. In addition, there was a correlation between the intake of $\mathrm{N} / \mathrm{kg}$ $\mathrm{LW}^{0.75}$ and the $\mathrm{MCV}$ indices obtained from the following equation:

$\mathrm{MCV}=54.813+188.62$ intake of $\mathrm{N} \mathrm{g} / \mathrm{kg} \mathrm{LW} \mathrm{LW}^{0.75}$, $\mathrm{R}^{2}=0.46, \mathrm{P}<0.05$. Still, there was no correlation between NB and DE intake $\left(\mathrm{R}^{2}=0.03, \mathrm{P}>0.05\right)$.

Treatments were observed to exert an effect on the apparent availability coefficients of $\mathrm{Ca}(\mathrm{F}=3.91, \mathrm{P}<0.05)$ and $\mathrm{P}(\mathrm{F}=18.88, \mathrm{P}<0.05)$, as well as the levels of $\mathrm{Ca}$ and $\mathrm{P}$ in feces ( $\mathrm{F}=3.85, \mathrm{P}<0.05, \mathrm{~F}=3.85, \mathrm{P}<0.05$, respectively), and $\mathrm{Ca}$ and $\mathrm{P}$ in urine $(\mathrm{F}=19.80, \mathrm{P}<0.05 \mathrm{~F}=3.85, \mathrm{P}<0.05$, respectively), in addition to the effect on the balance of $\mathrm{Ca}$ and $\mathrm{P}(\mathrm{F}=5.60, \mathrm{P}<0.05, \mathrm{~F}=3.85, \mathrm{P}<0.05$, respectively; Table 2). The different treatments also affected weight gain $(\mathrm{F}=7.4, \mathrm{P}<0.05)$. Lower weight gains, in turn, occurred when the capybaras were subjected to treatments with lower levels of nitrogen, calcium and phosphorus (Table 2). The daily amount of absorbed $\mathrm{N}$ (difference between intake and excretion in feces) was associated with the total daily intake of nitrogen per $\mathrm{kg} \mathrm{LW} \mathrm{LW}^{0.75}$, according to the following equation: $\mathrm{N}(\mathrm{abs}) / \mathrm{kg} \mathrm{LW}^{0.75}=-0.16+0.83 *$ intake $\mathrm{N} \mathrm{g} / \mathrm{kg}$ $\mathrm{LW}^{0.75}, \mathrm{R}^{2}=0.92, \mathrm{P}<0.05$ (Figure 1 ). This equation allowed to estimate that when $\mathrm{N}$ consumption is null the amount of $\mathrm{NMF}$ is $0.16 \mathrm{~g}$ of $\mathrm{N} / \mathrm{kg} \mathrm{LW} \mathrm{LW}^{0.75}$ day.

Likewise, the daily amounts of absorbed $\mathrm{Ca}$ and $\mathrm{P}$ were associated with the total daily intake of $\mathrm{Ca}$ and $\mathrm{P}$ per $\mathrm{kg} \mathrm{LW} \mathrm{LW}^{0.75}$, through the following equations: $\mathrm{Ca}(\mathrm{abs}) /$ $\mathrm{kg} \mathrm{LW} 0.75=-0.16+0.96 *$ intake Ca g/kg LW ${ }^{0.75}, \mathrm{R}^{2}=0.43$, $\mathrm{P}<0.05$ and $\mathrm{P}(\mathrm{abs}) / \mathrm{kg} \mathrm{LW} \mathrm{LW}^{0.75}=-0.09+0.76^{*}$ intake $\mathrm{P} \mathrm{g} / \mathrm{kg}$ $\mathrm{LW}^{0.75}, \mathrm{R}^{2}=0.60, \mathrm{P}<0.05$. These equations allowed for estimating that when calcium and phosphorus consumption is null $\mathrm{CaMF}=0.16 \mathrm{~g}$ of $\mathrm{Ca} / \mathrm{kg} \mathrm{LW} \mathrm{LW}^{0.75} *$ day and $\mathrm{PMF}=0.09 \mathrm{~g}$

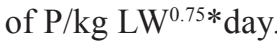

From the determination of $\mathrm{N}, \mathrm{P}$ and $\mathrm{Ca}$ amounts of metabolic origin in feces, TDN, TACa and TAP intakes for each treatment were determined (Table 2). These intakes were associated with total nitrogen (UN), calcium (UCa) and phosphorus (UP) present in urine, through the equations:

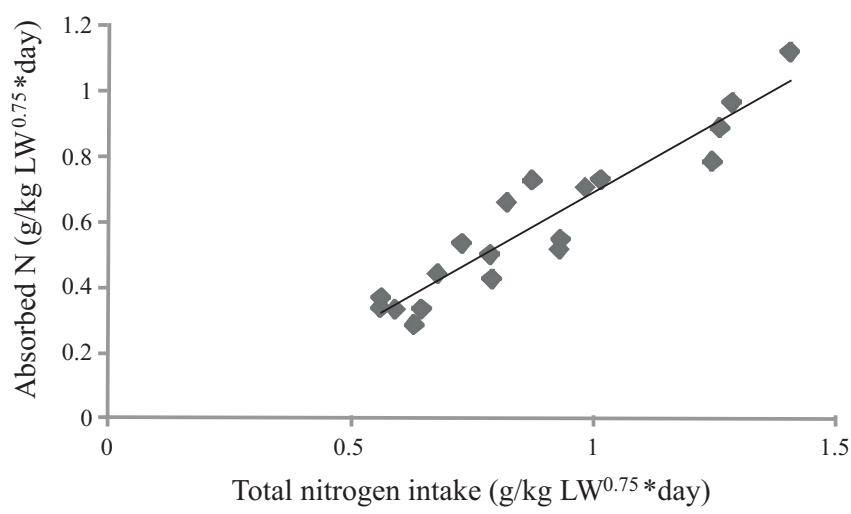

LW - live weight; Nabs - abosrbed nitrogen.

Figure 1 - Relationship between intake and amount of absorbed nitrogen, according the regression equation $\mathrm{Nabs} / \mathrm{kg}$ $\mathrm{LW}^{0.75}=-0.16+0.83 *$ intake of $\mathrm{N} \mathrm{g} / \mathrm{kg} \mathrm{LW}{ }^{0.75^{*}}$ day); $\mathrm{R}^{2}=0.92 ; \mathrm{P}<0.05$. 
$\mathrm{UN} / \mathrm{kg} \mathrm{LW}{ }^{0.75}=-0.05+0.56 *$ intake of TDN $(\mathrm{g}) / \mathrm{kg} \mathrm{LW}{ }^{0.75}$, $\mathrm{R}^{2}=0.84, \mathrm{P}<0.05$ (Figure 2);

$\mathrm{UCa} / \mathrm{kg} \mathrm{LW} \mathrm{LW}^{0.75}=-0.0002+0.0455^{*}$ intake of $\mathrm{TACa}$ $(\mathrm{g}) / \mathrm{kg} \mathrm{LW}{ }^{0.75}, \mathrm{R}^{2}=0.67, \mathrm{P}<0.05$; and $\mathrm{UP} / \mathrm{kg} \mathrm{LW} \mathrm{LW}^{0.75}=$ $-0.002+0.03$ intake of TAP $(\mathrm{g}) / \mathrm{kg} \mathrm{LW}^{0.75}, \mathrm{R}^{2}=0.75$, $\mathrm{P}<0.05$. With absolutely null intake of these elements, the amounts of $\mathrm{N}, \mathrm{Ca}$ and $\mathrm{P}$ found in urine were of endogenous origin and were estimated as: $\mathrm{EUN}=0.05 \mathrm{~g}$ of N/kg LW ${ }^{0.75}$; $\mathrm{EUCa}=0.0002 \mathrm{~g}$ of $\mathrm{Ca} / \mathrm{kg} \mathrm{LW} \mathrm{LW}^{0.75}$ and $\mathrm{EUP}=0.002 \mathrm{~g}$ of $\mathrm{P} / \mathrm{kg} \mathrm{LW}{ }^{0.75}$, respectively.

On the other hand, the daily intake of TDN/kg $\mathrm{LW}^{0.75}$ was associated with the nitrogen balances (NB), through the equation $\mathrm{NB}=-0.11+0.4362 *$ intake of TDN $/ \mathrm{kg} \mathrm{LW}^{0.75}$, $\mathrm{R}^{2}=0.76, \mathrm{P}<0.05$ (Figure 3 ). When NB was equal to zero, this equation was used for estimating the daily intake requirement, which was $0.25 \mathrm{~g}$ of $\mathrm{DN} / \mathrm{kg} \mathrm{LW} \mathrm{LW}^{0.75}$. This value represents a daily requirement of $1.56 \mathrm{~g}$ of digestible protein $/ \mathrm{kg} \mathrm{LW}^{0.75}$.

The daily intake values for TACa and TAP, in turn, were correlated with $\mathrm{Ca}$ and $\mathrm{P}$ balances $(\mathrm{CaB}$ and $\mathrm{PB})$ via the equations:

$\mathrm{CaB}=-0.12+0.41 *$ intake of TACa $(\mathrm{g}) / \mathrm{kg} \mathrm{LW} \mathrm{LW}^{0.75}$, $\mathrm{R}^{2}=0.80, \mathrm{P}<0.05$ and

$\mathrm{PB}=-0.15+0.10 *$ intake of $\mathrm{TAP}(\mathrm{g}) / \mathrm{kg} \mathrm{LW}^{0.75}$, $\mathrm{R}^{2}=0.99, \mathrm{P}<0.05$.

From these equations, daily demands of $0.30 \mathrm{~g} \mathrm{Ca} / \mathrm{kg}$ $\mathrm{LW}^{0.75}$ and $0.15 \mathrm{~g} \mathrm{P} / \mathrm{kg} \mathrm{LW}^{0.75}$, respectively, were estimated when the balances were null. These values correspond to

Table 2 - Descriptive statistics of the effects of treatments with different levels of nitrogen, calcium and phosphorus

\begin{tabular}{|c|c|c|c|c|c|}
\hline Item & T1 Mean & T2 Mean & T3 Mean & T4 Mean & Standard error of the mean \\
\hline \multicolumn{6}{|l|}{ Body weight } \\
\hline Mean $(\mathrm{kg})$ & 41.6 & 40.1 & 38.6 & 41.5 & 3.96 \\
\hline Change (kg) & $0.5 \mathrm{a}$ & $0.8 \mathrm{ab}$ & $3.1 b$ & $2.9 \mathrm{~b}$ & 0.06 \\
\hline \multicolumn{6}{|l|}{ Dry matter } \\
\hline Intake (g/kg LW ${ }^{0.75 * \text { day })}$ & 49.9 & 54.0 & 53.4 & 56.2 & 0.84 \\
\hline Aparent digestibility & 0.53 & 0.63 & 0.47 & 0.51 & 0.04 \\
\hline \multicolumn{6}{|l|}{ Gross energy } \\
\hline Intake (Kcal/kg LW ${ }^{0.75 * d a y)}$ & 210.2 & 213.4 & 211.7 & 216.5 & 2.81 \\
\hline Aparent digestibility & 0.52 & 0.54 & 0.48 & 0.53 & 0.03 \\
\hline \multicolumn{6}{|l|}{ Nitrogen } \\
\hline Intake (g/kg LW ${ }^{0.75 * d a y)}$ & $0.57 \mathrm{a}$ & $0.68 b$ & $0.97 \mathrm{c}$ & $1.30 \mathrm{~d}$ & 0.02 \\
\hline Fecal (g/kg LW ${ }^{0.75 *}$ day) & $0.23 \mathrm{a}$ & $0.28 \mathrm{ab}$ & $0.36 \mathrm{ab}$ & $0.37 \mathrm{~b}$ & 0.03 \\
\hline Urinary (g/kg LW ${ }^{0.75 * \text { day })}$ & $0.25 \mathrm{a}$ & $0.25 \mathrm{ab}$ & $0.36 \mathrm{ab}$ & $0.59 \mathrm{~b}$ & 0.03 \\
\hline Balance (g/kg LW ${ }^{0.75 * \text { day })}$ & $0.09 \mathrm{~b}$ & $0.15 b$ & $0.26 \mathrm{~b}$ & 0.34 & 0.05 \\
\hline Aparent digestibility & 0.60 & 0.58 & 0.63 & 0.71 & 0.05 \\
\hline True digestibility & 0.89 & 0.82 & 0.79 & 0.83 & 0.06 \\
\hline \multicolumn{6}{|l|}{ Calcium } \\
\hline Intake (g/kg LW ${ }^{0.75 * \text { day })}$ & $0.27 \mathrm{a}$ & $0.31 \mathrm{~b}$ & $0.34 \mathrm{c}$ & $0.37 \mathrm{~d}$ & 0.02 \\
\hline Fecal (g/kg LW ${ }^{0.75 * d a y)}$ & $0.17 \mathrm{a}$ & $0.14 \mathrm{a}$ & $0.16 \mathrm{a}$ & $0.20 \mathrm{a}$ & 0.00 \\
\hline Urinary $\left(\mathrm{g} / \mathrm{kg} \mathrm{LW} \mathrm{LW}^{0.75 * \text { day })}\right.$ & $0.00 \mathrm{a}$ & $0.01 \mathrm{~b}$ & $0.00 \mathrm{bc}$ & $0.00 \mathrm{c}$ & 0.00 \\
\hline Balance (g/kg LW ${ }^{0.75 * \text { day })}$ & $0.10 \mathrm{a}$ & $0.17 \mathrm{~b}$ & $0.18 \mathrm{~b}$ & 0.17 & 0.03 \\
\hline Aparent availability & $0.12 b$ & $0.30 \mathrm{ab}$ & $0.35 \mathrm{ab}$ & $0.37 \mathrm{a}$ & 0.08 \\
\hline True availability & 0.79 & 0.88 & 0.98 & 0.83 & 0.07 \\
\hline \multicolumn{6}{|l|}{ Phosphorus } \\
\hline Intake (g/kg LW ${ }^{0.75 * d a y)}$ & $0.21 \mathrm{a}$ & $0.25 b$ & $0.26 \mathrm{c}$ & $0.27 \mathrm{~d}$ & 0.03 \\
\hline Fecal (g/kg LW ${ }^{0.75 * d a y)}$ & $0.13 \mathrm{a}$ & $0.16 \mathrm{ab}$ & $0.18 \mathrm{a}$ & $0.24 b$ & 0.00 \\
\hline Urinary $\left(\mathrm{g} / \mathrm{kg} \mathrm{LW} \mathrm{LW}^{0.75 * \text { day })}\right.$ & $0.00 \mathrm{a}$ & $0.00 \mathrm{a}$ & $0.00 \mathrm{a}$ & $0.00 \mathrm{a}$ & 0.00 \\
\hline Balance (g/kg LW ${ }^{0.75 *}$ day) & $0.04 \mathrm{a}$ & $0.03 b$ & $0.10 \mathrm{~b}$ & 0.10 & 0.03 \\
\hline Aparent availability & $0.40 \mathrm{a}$ & $0.64 \mathrm{ab}$ & $0.66 \mathrm{~b}$ & $0.82 b$ & 0.09 \\
\hline True availability & 0.60 & 0.88 & 0.85 & 0.82 & 0.08 \\
\hline Hematocrit (\%) & 43.0 & 42.3 & 43.8 & 44.0 & 0.99 \\
\hline Hemoglobin (g/dL) & 14.3 & 14.1 & 14.6 & 14.6 & 0.34 \\
\hline Mean corpuscular volume (fL) & $167.3 \mathrm{a}$ & $154.7 \mathrm{a}$ & $275.1 \mathrm{~b}$ & $281.3 b$ & 30.08 \\
\hline $\mathrm{MCHC}(\mathrm{g} / \mathrm{dL})$ & 33.3 & 33.3 & 33.3 & 33.3 & 0.00 \\
\hline Cecotrophy occurrence (number/hour) & 0.42 & 0.37 & 0.25 & 0.42 & 0.14 \\
\hline
\end{tabular}

Means followed by different letters in the row differ by the Tukey test $(\mathrm{P}<0.05)$.

LW - live weight; MCHC - mean corpuscular hemoglobin concentration. 


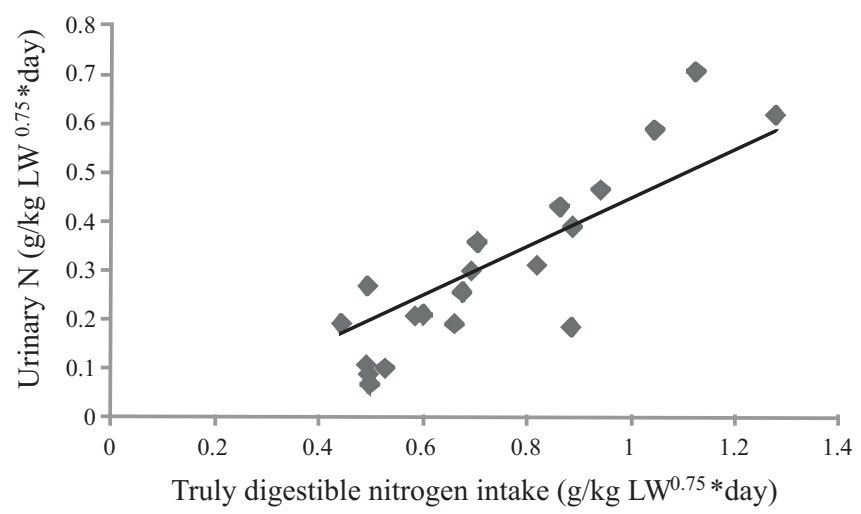

LW - live weight.

Figure 2 - Relationship between intake of truly digestible nitrogen (TDN) and the amount of nitrogen excreted in urine (UN), according to the regression equation $\mathrm{UN}=-0.05050 .5638 * \mathrm{TDN} ; \mathrm{R}^{2}=0.8342 ; \mathrm{P}<0.05$.

a diet containing $3.4 \mathrm{~g}$ of $\mathrm{Ca}$ (available) $/ \mathrm{kg}$ and $2.3 \mathrm{~g}$ of $\mathrm{P}$ (available) $/ \mathrm{kg}$ for an adult capybara in maintenance, with body weight of $40 \mathrm{~kg}$.

\section{Discussion}

Capybaras quickly adapted to the experimental routine. There was neither a decrease in feed intake nor injuries such as those verified by Bernardi (1993) when the capybaras were housed in metabolic cages. Furthermore, the apparent digestibility of DM and GE was similar to that determined in previous studies (González-Jiménez \& Escobar 1975; Baldizán et al., 1983; Bernardi, 1993).

The apparent digestibility coefficients of $\mathrm{N}$ determined in this study, however, were higher than those obtained by Gonzalez-Jimenez \& Escobar (1975). This difference can be explained by the experimental conditions adopted. In the previous study, the capybaras were housed in cages that may have inhibited the occurrence of cecotrophy and probably resulted in the collection of cecotrope along with feces. In capybaras, cecotropes have $37 \%$ more protein than feces (Mendes et al., 2000). Hence, the possible mixture of cecotrope with feces may have led to a reduction in the apparent digestibility of $\mathrm{N}$, thereby affecting the other results in the nitrogen balance assay.

The daily amount of $0.16 \mathrm{~g}$ of $\mathrm{N} / \mathrm{kg} \mathrm{LW}^{0.75}$ of fecal metabolic nitrogen is lower than that previously determined by González-Jiménez \& Escobar (1975) for capybaras $\left(0.48 \mathrm{~g}\right.$ of $\left.\mathrm{N} / \mathrm{kg} \mathrm{LW}{ }^{0.75}\right)$. This result further reinforces the assumption that, in the previous study, cecotrope was collected along with the feces, thus leading

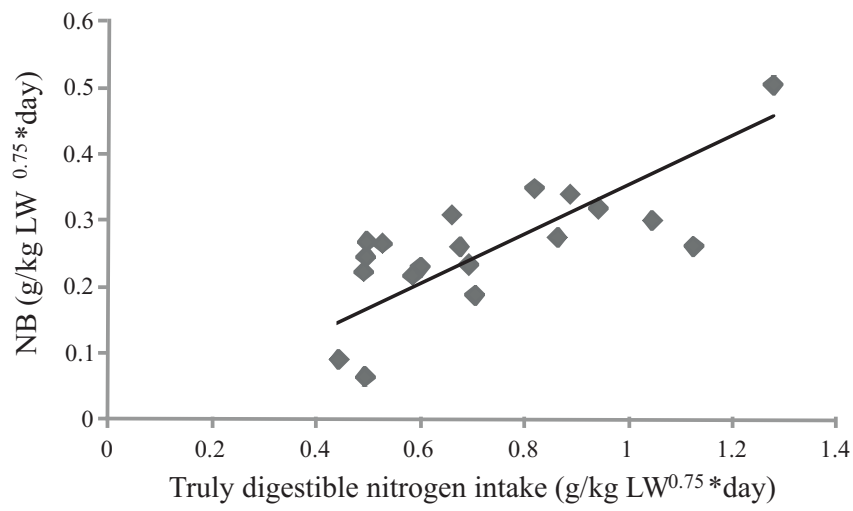

LW - live weight.

Figure 3 - Relationship between nitrogen balance (NB) and daily intake of truly digestible nitrogen (TDN) according the regression equation $\mathrm{NB}=-0.38+1.93 \mathrm{TDN} / \mathrm{kg} \mathrm{LW}{ }^{0.75}$; $\mathrm{R}^{2}=0.69 ; \mathrm{P}<0.05$.

to overestimating the nitrogen losses of metabolic origin. Moreover, when the nitrogen balance is equal to zero (null), the values estimated for the daily requirements of digestible nitrogen $\left(0.25 \mathrm{~g}\right.$ of $\left.\mathrm{DN} / \mathrm{kg} \mathrm{LW}{ }^{0.75}\right)$ and therefore those regarding digestible protein $\left(1.56 \mathrm{~g} / \mathrm{kg} \mathrm{LW}{ }^{0.75}\right)$ represent one-third less than 0.4 and $2.5 \mathrm{~g} / \mathrm{kg} \mathrm{LW}{ }^{0.75}$, respectively, as determined by González-Jiménez \& Escobar (1975). These results underline the importance of cecotrophy in the nitrogen-protein balance of capybaras.

The capybaras observed in this study showed their natural cecotrophy behavior. The occurrence of this act was similar to the hourly frequency of 0.3 acts observed by Mendes et al. (2000). Moreover, there was no relationship between the intake of $\mathrm{N}, \mathrm{P}$ and $\mathrm{Ca}$ with the occurrence of cecotrophy acts. Mendes et al. (2000) proposed that this behavior was optional and could be associated with the nutritional levels of the diet of capybaras. In free-living conditions, capybaras perform cecotrophy more often during the dry season, when the nutritional quality of the consumed forage is of poorer quality, unlike the rainy season, when the grass protein content is higher (Herrera, 1985). In rabbits, there has been a higher occurrence of cecotrophy when diets with low protein levels were provided (Cheeke, 1994). The results, however, reveal that the use of $\mathrm{N}$ did not affect the occurrence of this act, at least at the tested levels.

On the other hand, there was a wide variation in the occurrence of this act. Also, the animals whose cecotrophy behavior was less frequent were those with higher levels of mean corpuscular volume (MCV). The mean values of hematocrit, hemoglobin and mean corpuscular hemoglobin concentration (CHCM) were similar to those found in free- 
living capybaras (Madella et al., 2006). Yet the MCV values determined in this study were higher than those verified by Madella et al. (2006). This erythrocyte index is useful in the classification of anemia; aside from this, when MCV is increased, it may indicate macrocytic anemia caused by vitamin $\mathrm{B}_{12}$ and/or folic acid deficiencies (Duncan \& Prasse, 1982). Since vitamin $B_{12}$ can be obtained via cecotrophy, it is not usually necessary to supplement the diets of capybaras (Mendes et al., 2000). The increased MCV in the present study may indicate that capybaras did not perform sufficient cecotrophy acts to supply this vitamin. This is corroborated by the fact that capybaras living in the natural environment perform on average one act of cecotrophy per hour (Herrera, 1985). This frequency is therefore three times greater than that recorded in the present study. One may therefore conclude that when a protein concentrate is supplied, capybaras need to add vitamin $B_{12}$ to their diets to avoid anemia.

Energy intake can be alternatively associated with the occurrence of cecotrophy. When rabbits are fed diets with low caloric levels, cecotrophy is maximized (Jenkins, 1999). Since the digestible energy intake in the present study was similar among all treatments and to that provided by Mendes et al. (2000), it is possible that cecotrophy is related to the amount of consumed energy, which should be verified in future studies.

Capybaras consumed on average $116.6 \pm 17.7 \mathrm{kcal}$ of digestible energy $/ \mathrm{kg} \mathrm{LW}^{0.75}$. This value is one and a half times their daily requirements $\left(65.5 \mathrm{Kcal} / \mathrm{kg} \mathrm{LW}^{0.75}\right.$, Ojasti, 1991). The reduced dietary energy intake could negatively influence the utilization of the dietary protein, since animals can use the protein in the diet to meet their energy requirements (Van Soest, 1994). In fact, this did not occur in this study, as verified by the absence of a relationship between digestible energy intake and nitrogen balance. This could result in an overestimation of the protein demands of capybaras, as seen in the study of Carl \& Brown (1985) for determining the protein requirements of peccaries (Pecari tajacu).

The nutritional requirements for the maintenance of capybaras are lower than those of domestic and other wild species. The daily digestible protein required for the maintenance of rabbits, for example, is $3.03 \mathrm{~g} / \mathrm{kg} \mathrm{LW}^{0.75}$ (Lv et al., 2009). If on the one hand the daily requirement of Nelore cattle is $4.03 \mathrm{~g} / \mathrm{kg} \mathrm{LW}^{0.75}$ (Véras et al., 2007), on the other hand, that of peccaries - a wild species with potential for domestication - is $5.1 \mathrm{~g} / \mathrm{kg} \mathrm{LW}^{0.75}$ (Carl \& Brown, 1985). In turn, the calcium and phosphorus requirements are lower than those for domestic species. Pigs, for example, require $6.5 \mathrm{~g}$ of $\mathrm{Ca} / \mathrm{kg}$ of body weight and $3.2 \mathrm{~g}$ of $\mathrm{P} / \mathrm{kg}$ of body weight for finishing/maintenance (Rostagno et al., 2005). The low nutritional requirements for the maintenance of capybaras, both domestic and wild species with zootechnical potential, help in the process of domestication of the species.

\section{Conclusions}

Capybaras have a lower protein-nitrogen requirement for maintenance than that previously established. The digestible nitrogen and available calcium and phosphorus $\left(0.25 \mathrm{~g}\right.$ of $\mathrm{N} / \mathrm{kg} \mathrm{LW}{ }^{0.75}, 0.30 \mathrm{~g}$ of $\mathrm{Ca} / \mathrm{kg} \mathrm{LW}{ }^{0.75}$ and $0.15 \mathrm{~g}$ of $\mathrm{P} / \mathrm{kg} \mathrm{LW} \mathrm{LW}^{0.75}$, respectively) levels required for the maintenance of capybaras are lower than those needed by domestic species and other wild species with zootechnical potential.

\section{Acknowledgements}

The authors are are grateful to Susan Casement for valuable comments on this manuscript and to Diego Armando Bandeira Alves, for help with data collection. Thanks also go to Waldemar Barretto for assistance in the Laboratory of Plant Tissues of CEPEC/CEPLAC and to Prof. Dr. Alexandre Munhoz for hematological analyses. Research for this manuscript was supported by FAPESB (APP0007/2009). Sérgio Luiz Gama Nogueira-Filho, Marco Antônio Galvão de Carvalho and Selene Siqueira da Cunha Nogueira were supported by CNPq (Process no. 300587/2009-0, 504969/2010-2 and 306154/2010-2, respectively) and Alcester Mendes by CAPES/PNPD.

\section{References}

ALTMMAN, J. Observational study of behaviour: sampling methods. Behaviour, v.49, p.227-265, 1974.

BALDIZÁN, A.; DIXON, R.M.; PARRA, R. Digestion in the capybara (Hydrochoerus hydrochaeris). South African Journal of Animal Science, v.13, p.27-28, 1983.

BERNARDI, L.G. Efeito dos níveis crescentes de volumoso sobre a digestibilidade de nutrientes de rações para capivaras (Hydrochoerus hydrochaeris hydrochaeris, L. 1766). 1993. 203f. Dissertação (Mestrado em Nutrição Animal e Pastagens) - Escola Superior de Agricultura "Luiz de Queiroz"/Universidade de São Paulo, Piracicaba.

BORGES, P.A.; DOMINGUEZ-BELLO, M.G.; HERRERA, E.A. Digestive physiology of wild capybara. Journal Comparative Physiology B, v.166, p.55-60, 1996.

CARL, G.R.; BROWN, R.D. Protein requirements of adult collared peccaries. Journal of Wildlife Management, v.49, p.351-55, 1985.

CHEEKE, P.R. Rabbit feeding and nutrition. New York: Academic Press, 1987. 376p

CHEEKE, P.R. Nutrition and nutritional diseases. In: MANNING, P.J.; RINGLER, D.H.; NEWCOMER, C.E. (Eds.) The biology of the laboratory rabbit. 2.ed. New York: Academic Press, 1994. p.321-323. 
DUNCAN, J.R.; PRASSE, K.W. Patologia clínica veterinária. Rio de Janeiro: Guanabara Koogan, 1982. 217p.

GONZÁLEZ-JIMÉNEZ, E.; ESCOBAR, A. Digestibilidad comparada entre chiguire (Hydrochoeris hydrochaeris), conejos y ovinos con raciones de diferentes proporciones de forrages y concentrado. Revista Agronomia Tropical, v.25, p.283-290, 1975.

GONZÁLEZ-JIMÉNEZ, E., ESCOBAR, A., CAIRES, O. Un metodo para detectar coprofagia en chiguires - Resultados. In: SEMINÁRIO SOBRE Chiguires_Hydrochoerus hydrochaeris. Y Babas_Caiman crododilus, 2., 1976, Maracay, Venezuela. Programa y resumenes... Maracay, Venezuela, 1976. p.1.

GROSS, J.C.M.S.; SPILLMAN, D.M. Fiber digestion in mammals. Pakistan Journal of Biological Sciences, v.6, p.1564-1573, 2003.

HERRERA, E.A. Coprophagy in capybara, Hydrochoerus hydrochaeris. Journal of Zoology, Ser. A, v.207, p.616-619, 1985.

JENKINS, J.R. Feeding recommendations for the house rabbit. Veterinary Clinics of North America: Exotic Animal Practice, v.2, p.143-151, 1999.

KOLB, E. Fisiologia veterinária. 4.ed. Rio de Janeiro: Guanabara Koogan, 1984. 612p.

LV, J.; CHEN, M.; QIAN, L. et al. Requirement of crude protein for maintenance in a new strain of laboratory rabbit. Animal Feed Science and Technology, v.151, p.261-267, 2009.

MADELLA, D.A.; RODRIGUES NETO, E.J.; FELISBERTO, M.E. et al. Valores hematológicos de capivaras (Hydrochoerus hydrochaeris) Rodentia:Hydrochoeridae) de vida livre na região de Campinas-SP. Ciência Rural, v.36, p.1321, 2006.

MAYNARD, L.A.; LOOSLI, J.K.; HINTZ, H.F. et al. Nutrição animal. 3.ed. Rio de Janeiro: Freitas Bastos, 1984. 736p.

MENDES, A.C.; DA NOGUEIRA, S.S.; LAVORENTI, A. et al. A note on the cecotrophy behavior in capybara (Hydrochaeris hydrochaeris). Applied Animal Behaviour Science, v.66, p.161-167, 2000.

NOGUEIRA， S.S.C.; NOGUEIRA-FILHO S.L.G.; OTTA, E. et al. Determination of the causes of infanticide in capybara (Hydrochaeris hydrochaeris) groups in captivity. Applied Animal Behavior Science, v.62, p.351-357, 1999.

NOGUEIRA, A.R.A.; SOUZA, G.B. Manual de laboratórios: solo, água, nutrição vegetal, nutrição animal e alimentos. São Carlos: Embrapa Pecuária Sudeste, 2005. 313p.

NOGUEIRA-FILHO S.L.G.; NOGUEIRA S.C.C. Captive breeding programs as an alternative for wildlife conservation in Brazil. In: KIRSTEN S., FRAGOSO J.M.V.; BODMER E.R. (Eds.) People in nature: Wildlife management and conservation in Latin America. New York: Columbia University Press, 2004. p.171-190.

OJASTI, J. Human exploitation of capybara. In: ROBINSON, J.G.; REDFORD, K.H. (Eds.). Neotropical wildlife use and conservation. Chicago: The University of Chicago Press, 1991. p.236-252.

POND, W.G.; CHURCH, D.C.; POND, K.R. et al. Basic animal nutrition and feeding. 5.ed. New Jersey: John Wiley \& Sons, Incorporated, Hobeken, 2004. 580p.

ROSTAGNO, H.S.; ALBINO, L.F.T.; DONZELE, J.L. et al. Tabelas brasileiras parágrafo aves e suínos: Composição de alimentos e exigências nutricionais. 2.ed. Viçosa, MG: Editora UFV, 2005. 186p.

VAN SOEST, P.J. Nutritional ecology of the ruminant. 2.ed. Ithaca, New York: Cornell University Press, 1994. 476p.

VÉRAS, R.M.L.; VALADARES FILHO, S.C.; VALADARES R.D. Balanço de compostos nitrogenados e estimativa das exigências de proteína de mantença de bovinos Nelore de três condições sexuais. Revista Brasileira de Zootecnia, v.36, n.4, p.1212-1217, 2007. 